\title{
Stabilitas Bank: Sebuah Pengujian Berdasarkan Teori Resource Based View
}

\author{
Dita Rari Dwi RT \\ Program Studi S1 Akuntansi STIE Ekuitas, Bandung, Indonesia
}

\begin{abstract}
Abstrak. This study aims to examine banking service technology and intellectual capital to the stability of the bank. The results of panel data regression analysis on 81 commercial banks in Indonesia with observations in 2013 - 2015 obtained from the results of financial service technology and intellectual capital have a significant effect on the stability of commercial banks in Indonesia. Likewise, with each component of intellectual capital consisting of VAHU, STVA has a significant effect on bank stability in a positive direction, while VACA has an influence on bank stability in a negative direction. Both analyzes show that financial service technology and intellectual capital both calculated with VAIC and each component of VAIC show no difference in effect on bank stability. The findings of this study strengthen the RBV theory where tangible resources and intangible resources are the main capital that must be owned by the company in order to achieve competitive advantage in the era of industrial development 4.0.
\end{abstract}

Keywords. Bank stability; Intellectual Capital (IC); RBV.

Abstrak. Penelitian ini bertujuan untuk mengkaji teknologi layanan perbankan dan modal intelektual terhadap stabilitas bank. Hasil analisa regresi data panel terhadap 81 bank umum di Indonesia dengan pengamatan selama 2013 - 2015 diperoleh hasil teknologi layanan keuangan dan intellectual capital berpengaruh signifikan terhadap stabilitas bank umum di Indonesia. Begitu pula dengan masing - masing komponen modal intelektual yang terdiri dari VAHU, STVA berpengaruh signifikan terhadap stabilitas bank dengan arah positif, sedangkan VACA memiliki pengaruh terhadap stabilitas bank dengan arah negatif. Kedua analisis menunjukkan teknologi layanan keuangan dan modal intelektual baik yang dihitung dengan nilai VAIC maupun masing - masing komponen VAIC menunjukkan tidak ada perbedaan pengaruhnya terhadap stabilitas bank. Temuan penelitian ini memperkuat teori RBV dimana sumber daya berwujud dan sumber daya tidak berwujud merupakan modal utama yang harus dimiliki oleh perusahaan dalam rangka mencapai keunggulan bersaing di era perkembangan industri 4.0.

Kata Kunci. Intellectual Capital (IC); Stabilitas Bank; RBV.

Correspondence. Jl. PHH Mustofa No. 31 Bandung, dita.raridwi@ekuitas.ac.id

History of article. Received: April 2019, Revision: Juli 2019, Published: September 2019

\section{PENDAHULUAN}

Konsep "competition-fragility" menjadi trend baru dalam bidang penelitian perbankan. (Berger, Klapper, \& Ariss, 2009) menjelaskan hubungan antara kompetisi dan kerapuhan dicirikan dengan semakin menurunnya jumlah bank yang disebabkan kompetisi yang semakin ketat, penurunan tingkat keuntungan, dan mendorong pengambilan risiko. Mereka menemukan kerapuhan bank yang diuji dengan menggunakan z-index disebabkan oleh kekuatan pasar yang terdiri dari indeks Lerner, Herman Herfindal Index (HHI) produk simpanan maupun produk pinjaman, ukuran bank, dan pendapatan per kapita.

Penelitian (Nicolo \& Lucchetta, 2013), (Fernandez \& Garcia, 2015) menemukan konsentrasi pasar bank tidak berpengaruh terhadap stabilitas bank. Bahkan dalam penelitiannya mereka menemukan bahwa kerapuhan bank bukan disebabkan oleh tingkat kompetisi namun disebabkan oleh kemampuan bank untuk beroperasi secara efisien. Temuannya ini sesuai dengan teori $x$-efficiency yang dicetuskan oleh (Leibenstein, 1966).

Perbedaan temuan hasil penelitian ini menjadi landasan peneliti untuk mengkaji faktor lain yang menentukan stabilitas bank. Penelitian stabilitas bank di Indonesia menjadi hal yang menarik untuk dikaji lebih jauh, mengingat dalam lima tahun terakhir jumlah bank dengan total aset kurang dari 1 triliun Rupiah, 1 - 10 triliun Rupiah menunjukkan penurunan sedangkan bank dengan total aset $10-50$ triliun dan di atas 50 triliun menunjukkan peningkatan. Informasi ini mencerminkan kepemilikan aset mengindikasikan kemampuan mempertahankan bisnis yang berbeda. 
Perkembangan jumlah perbankan berdasarkan kepemilikan aset selama tahun 2012 - 2017, diduga dipengaruhi oleh faktor perkembangan teknologi layanan keuangan yang digunakan oleh perbankan dengan aset yang besar. (Hauswald \& Marquez, 2003) dalam penelitiannya mengungkapkan terdapat dua dimensi kemajuan teknologi mempengaruhi persaingan dalam layanan keuangan, yakni dimensi kemampuan pemrosesan informasi dan kemampuan memperoleh informasi dari eksternal sebagai implementasi dari konsep "big data". (Eisdorfer \& Hsu, 2011) menemukan perusahaan yang bangkrut sebagai akibat dari kompetisi teknologi mengalami penurunan yang lebih besar dalam pendapatan dan harga saham.

Bank dengan penguasaan teknologi yang memadai akan meningkatkan produktivitas usahanya, peningkatan produktivitas akan meningkatkan penguasaan pasar yang ditandai dengan meningkatnya indeks Lerner (Koetter \& Noth, 2013). Kedua temuan tersebut memberikan petunjuk bahwa penguasaan teknologi dalam aktivitas bisnis perusahaan dapat memberikan efek disrupsi bagi perusahaan lainnya namun disisi lain menjadikan bank mampu meraih keuntungan secara maksimal. Selain pada penguasaan teknologi, bank harus memiliki sumber daya manusia yang kompeten. Penelitian (Chen, Cheng, \& Hwang, 2005; D. G. Mavridis, 2005; Pulic, 1998) telah mengungkapkan bahwa sumber daya manusia dengan kompetensi yang memadai menjadi kunci bank untuk memenangkan persaingan.

Menyadari peran penting sumber daya manusia dalam tata kelola perbankan di Indonesia, OJK telah mewajibkan bank umum untuk menyediakan biaya pendidikan dan pelatihan minimal lima persen (5\%) dari total anggaran sumber daya manusia per tahun (Surat Keputusan Direksi Bank Indonesia, 1999). Pengukuran dampak dari pengembangan sumber daya manusia terhadap kinerja perbankan di Indonesia sampai saat ini belum ada, oleh karena itu pengukuran pengembangan sumber daya manusia dalam penelitian ini ditentukan melalui Value Added Intellectual Capital (VAIC) dengan berbasis pada data akuntansi yang terdiri dari capital employed efficiency (VACA), human capital efficiency (VAHU), serta structural capital efficiency (STVA) (Pulic, 1998).

Semenjak Pulic memformulasikan VAIC, telah banyak penelitian di bidang perbankan yang dilakukan, (D. G. Mavridis, 2005) melakukan penelitian terhadap bank di Yunani, (Kamath, 2008) di India, (Hanum, Kamal, Mat, Rahim, \& Husin, 2011) di Malaysia, (Heryana \& Saputra, 2013) di Indonesia, dan (Joshi, Cahill, Sidhu, \& Kansal, 2013) di Australia. Penelitian tersebut, pada umumnya melakukan pengujian VAIC terhadap kinerja keuangan yang diukur dengan ROA, ROI, CAR, dan Pertumbuhan Pendapatan, sementara terhadap aspek stabilitas bank belum ada yang meneliti.

Berdasarkan hasil identifikasi terhadap penelitian terdahulu maupun kondisi empiris perbankan di Indonesia selama tahun 2012 - 2017, penelitian ini bertujuan untuk menguji secara empiris pengaruh teknologi layanan bank dan modal intelektual terhadap stabilitas bank. Selain itu, hasil penelitian diharapkan dapat memberikan jawaban mengenai relevansi regulasi perbankan di Indonesia terkait dengan kebijakan investasi teknologi informasi dan pengembangan sumber daya manusia era industri 4.0.

\section{KERANGKA PENELITIAN \& HIPOTESIS}

\section{Teori Resource Based View}

Jauh sebelum munculnya era ekonomi berbasis pengetahuan, peran sumber daya dalam menentukan posisi persaingan perusahaan telah lama disadari. Penrose pada tahun 1959 sebagaimana yang dikutip oleh Rugman dan Verbeke (2002), Kor dan Mahoney (2004), serta Newbert (2007) mengemukakan pandangannya melalui sebuah teori yang dikenal luas yakni teori RBV. Teori ini menjelaskan bahwa sumberdaya perusahaan bersifat heterogen dan jasa produktif yang berasal dari sumberdaya perusahaan memberikan karakter unik bagi tiap perusahaan. Jika perusahaan dapat memanfaatkan sumberdayanya secara maksimal, maka perusahaan memiliki suatu keunggulan kompetitif serta memiliki daya saing terhadap para kompetitornya.

Sumber daya yang dimaksud dalam teori RBV, yakni sumber daya yang memiliki karakteristik berikut: Pertama, sumberdaya mampu mendukung kemampuan perusahaan dalam memenuhi kebutuhan para pelanggan yang lebih baik dibandingkan dengan perusahaan kompetitor; Kedua, jumlah sumberdaya yang tersedia terbatas atau langka dan tidak mudah ditiru. Terdapat empat karakteristik yang mengakibatkan sumberdaya menjadi sulit ditiru, yaitu sumberdaya unik secara fisik, memerlukan waktu yang lama serta biaya yang besar untuk memperolehnya, sumberdaya unik yang sulit dimiliki dan dimanfaatkan pesaing, dan sumberdaya yang memerlukan investasi modal yang besar untuk mendapatkannya; Ketiga, sumberdaya tersebut dapat memberikan keuntungan bagi perusahaan. Semakin banyak keuntungan yang menjadi milik perusahaan sebagai akibat dari pemanfaatan sumberdaya tertentu, maka semakin berharga sumberdaya tersebut; Keempat, sumber daya tersebut memiliki daya tahan (durability) (Penrose dalam Kor dan Mahoney 2004; Acedo dkk, 2006). 
Sejalan dengan pandangan teori tersebut, maka sumber daya yang dibutuhkan dalam menciptakan keunggulan bersaing serta mampu menjadi faktor guna mempertahankan keberlangsungan perusahaan, dapat dikelompokkan menjadi sumberdaya berwujud dan tak berwujud. Secara praktis sumberdaya berwujud sangat mudah diidentifikasi dan dinilai, contohnya sumber daya fisik seperti teknologi dan sumberdaya keuangan. Sebaliknya sumberdaya tak berwujud merupakan sumberdaya yang tidak tampak namun dapat dirasakan keberadaanya. Beberapa sumberdaya tak berwujud, dapat dikelompokan kedalam: modal manusia (keterampilan, pengalaman, pendidikan, loyalitas), modal relasional (hubungan atau relasi dengan pasar), serta modal organisasi (merek dagang, prestise, reputasi, dan budaya organisasi). (Werterfelt seperti yang dikutip oleh Helfat dan Peteraf 2003; Ray dkk. 2004; Acedo dkk. 2006).

\section{Teknologi Layanan Bank dan Stabilitas Bank}

Layanan keuangan perbankan di berbagai negara kini telah mengalami pergeseran yang sangat pesat. Layanan keuangan tidak lagi bisa dilakukan secara manual, akan tetapi semua layanan saat ini berbasis pada pemanfaatan teknologi informasi. (Hauswald \& Marquez, 2003) mengidentifikasi ada dua hal perkembangan teknologi layanan perbankan saat ini, yakni dalam aspek peningkatan proses pengolahan informasi, dan kemampuan untuk mengakses informasi eksternal yang menyangkut nasabah atau calon nasabah. Mereka menyimpulkan, institusi keuangan yang menerapkan layanan keuangan berbasis teknologi mampu menekan biaya lebih rendah dan bahkan memiliki informasi yang melimpah.

Peran pemanfaatan teknologi pada industri perbankan dinilai akan mampu menyelamatkan eksistensi bank itu sendiri. Mengenai hal ini (Eisdorfer \& Hsu, 2011) dalam penelitiannya menemukan adanya hubungan yang kuat antara persaingan teknologi dan perusahaan dalam kebangkrutan. Bahkan menurutnya, kemampuan perusahaan untuk melakukan inovasi melalui pemanfaatan teknologi menjadi prediktor yang lebih relevan dalam memprediksi kebangkrutan perusahaan, dibandingkan dengan pengukuran z-score maupun credit rating.

Penerapan layanan perbankan berbasis IT perlu direncanakan secara memadai dengan mendapatkan pendanaan yang mencukupi agar hasil dari pemanfaatan IT benar - benar berdampak nyata dalam mengokohkan posisinya dalam persaingan. Secara empiris penelitian (Koetter \& Noth, 2013) telah membuktikan investasi teknologi informasi yang dilakukan oleh bank di Jerman selama tahun 1996 2006 memiliki dampak terhadap peningkatan kekuatan pasar dan berdampak terhadap profitabilitas.

Sathye \& Sathye (2017) menjelaskan pada perbankan di India, ATM masih merupakan sarana yang efektif untuk bank dalam rangka memperoleh pendapatan non bunga. Begitu pula di Kenya, inovasi keuangan berbasis teknologi (diantaranya ATM) memiliki pengaruh signifikan terhadap pendapatan non-bunga yang diperoleh. Studi ini merekomendasikan semua pemangku kepentingan di bank komersial untuk mengambil investasi yang dilakukan terhadap produk inovasi keuangan berbasis teknologi sebagai strategi untuk meningkatkan pendapatan non-bunga (Alubisia, 2018).

Berpijak pada penelitian (Koetter \& Noth, 2013), Sathye \& Sathye (2017), dan (Alubisia, 2018), dalam konteks keuangan perbankan teknologi layanan bank terbukti memberikan dampak terhadap pendapatan bank. Ini berarti kehadiran teknologi layanan bank ini menjadi faktor yang menentukan profitabilitas. Pada bagian lain profitabilitas dapat dikaitkan sebagai parameter dalam menilai stabilitas bank. Stabilitas bank merupakan suatu keadaan yang menggambarkan kemampuan bank untuk menjalankan fungsi intermediasi, yang antara lain pemupukan dana pihak ketiga, penyaluran pinjaman, serta layanan jasa pembayaran (Beck, 2008). Stabilitas bank itu sendiri merupakan proksi dari probabilitas kegagalan bank dengan mengkombinasikan ukuran profitabilitas, leverage, dan volatilitas tingkat keuntungan bank menjadi sebuah ukuran stabilitas bank (Berger et al., 2009; Wibowo, 2016).

Berdasarkan argumentasi teoritis, hipotesis yang dikembangkan adalah sebagai berikut:

$\mathrm{H}_{1}$ : Teknologi layanan bank berpengaruh terhadap stabilitas bank.

\section{Modal Intelektual dan Stabilitas Bank}

Era ekonomi berbasis pengetahuan yang berkembang di akhir abad 20 semakin memperkuat pentingnya sumber daya yang berorientasi pada pemanfaatan pengetahuan sebagai kunci untuk memenangkan persaingan (Campos \& de Pablos, 2004). Pengetahuan yang dimaksud oleh (Campos \& de Pablos, 2004) adalah pengetahuan yang bersifat tacit yakni pengetahuan yang hanya ada dalam pikiran seseorang dan belum terdokumentasikan. Pengetahuan yang bersifat tacit ini merupakan model sumber daya yang dinilai sesuai dengan karakteristik sumber daya yang dimaksud dalam teori RBV.

Pengukuran atas pengetahuan tacit yang dimiliki oleh seseorang, merupakan hal yang sulit untuk dilakukan. Namun (Pulic, 1998) telah mengusulkan 
model pengukuran pengetahuan tacit ini dalam model VAIC dengan menggunakan basis data akuntansi. la dinilai telah berhasil memberikan keyakinan kepada para praktisi dan akademisi bahwa VAIC dapat dijadikan sebagai ukuran dalam mengevaluasi nilai tambah dari intelektual yang dimiliki oleh sumber daya manusia pada suatu perusahaan.

Pulic (1998) mengekspresikan pengukuran nilai tambah modal intelektual diperoleh dari penjumlahan antara Value Added Capital Employed (VACA), Value Added Human Capital (VAHU), dan Structural Capital Value Added (STVA). VACA merupakan indikator untuk Value Added (VA) yang diciptakan oleh satu unit dari physical capital. Rasio ini menunjukkan kontribusi yang dibuat oleh setiap unit CE (Capital Employed) terhadap value added perusahaan. Sedangkan VAHU menunjukkan berapa banyak VA dapat dihasilkan dengan dana yang dikeluarkan untuk tenaga kerja. Rasio ini menunjukkan kontribusi yang dibuat oleh setiap rupiah yang diinvestasikan dalam HC terhadap value added perusahaan. Dan STVA menunjukkan jumlah SC yang dibutuhkan untuk menghasilkan 1 Rupiah dari VA yang merupakan indikasi bagaimana keberhasilan SC dalam penciptaan nilai.

Berbagai penelitian yang mengaitkan VAIC maupun masing - masing komponennya terhadap kinerja keuangan perusahaan telah banyak dilakukan. Diantaranya penelitian (Maheran \& Muhammad, 2009) yang menemukan VAIC berpengaruh signifikan terhadap ROA pada sektor keuangan di Malaysia. Penelitian (Clarke, Seng, \& Whiting, 2011) juga menemukan bahwa VAIC berpengaruh positif terhadap ROA, ROE, pertumbuhan pendapatan, dan produktivitas pegawai pada perbankan di Australia. Begitu pula dengan masing - masing komponen dalam VAIC yang terdiri dari HCE, CEE, dan SCE yang berpengaruh terhadap masing - masing komponen kinerja keuangan. Hasil penelitian (Sumedrea, 2013) terhadap perusahaan yang terdaftar di Bursa Efek Rumania juga mengungkapkan, VAIC berpengaruh positif terhadap ROA.

Hasil penelitian terdahulu telah banyak mengungkapkan ROA menjadi salah satu indikator penting dalam menilai kemampuan bank untuk tetap bertahan dalam melaksanakan bisnisnya. Oleh karenanya, dalam sejumlah penelitian menggunakan ROA sebagai komponen untuk melakukan pengukuran stabilitas bank. Stabilitas bank yang diproksikan dengan Z-index adalah sebuah proksi dari probabilitas kegagalan bank dengan mengkombinasikan ukuran profitabilitas bank, leverage, dan volatilitas tingkat keuntungan bank menjadi sebuah ukuran stabilitas bank (Wibowo, 2016).
Berdasarkan argumentasi teoritis tentang modal intelektual dan stabilitas bank, hipotesis yang dikembangkan adalah sebagai berikut:

$\mathrm{H}_{2}$ : VAIC berpengaruh signifikan terhadap stabilitas bank.

$\mathrm{H}_{3}$ : VACA berpengaruh signifikan terhadap stabilitas bank.

$\mathrm{H}_{4}$ : VAHU berpengaruh signifikan terhadap stabilitas bank.

$\mathrm{H}_{5}$ : STVA berpengaruh signifikan terhadap stabilitas bank.

\section{METODE PENELITIAN}

Variabel independepen dalam penelitian ini terdiri dari teknologi layanan perbankan dan modal intelektual sebagai variabel independen, sedangkan variabel dependen adalah stabilitas bank. Penjelasan masing - masing variabel diuraikan sebagai berikut:

Variabel Independen

1. Teknologi Bank

Teknologi layanan bank dalam penelitian ini diukur dengan ketersediaan jumlah ATM yang dimiliki oleh masing - masing bank sebagai proksi dari teknologi layanan bank (Alubisia, 2018; Sathye \& Sathye, 2017).

\section{Modal Intelektual}

Modal intelektual diukur berdasarkan nilai tambah yang diciptakan oleh physical capital (VACA), human capital (VAHU), dan structural capital (STVA). Kombinasi ketiganya diformulasikan sebagai VAIC (Pulic, 1998). Perhitungan VAIC secara terperinci dijelaskan sebagai berikut:

VAIC=VACA+VAHU+STVA

Dimana:

VACA $=$ Value Added Capital Employed, adalah indikator untuk Value Added (VA) yang diciptakan oleh satu unit dari physical capital. Rasio ini menunjukkan kontribusi yang dibuat oleh setiap unit CE (Capital Employed) terhadap value added organisasi. Dengan demikian VACA dirumuskan sebagai:

$$
\text { VACA }=\frac{V A}{C E}
$$

Dimana:

$\mathrm{VA}=\mathrm{OP}+\mathrm{E}+\mathrm{D}(\mathrm{OP}=$ Laba Operasi; $\quad \mathrm{EC}$ = Beban Karyawan; D=Depresiasi)

$\mathrm{CE}=$ Dana yang tersedia (ekuitas)

VAHU $=$ Value Added Human Capital menunjukkan berapa banyak VA dapat dihasilkan dengan dana yang dikeluarkan untuk tenaga kerja. Rasio ini menunjukkan kontribusi yang 
dibuat oleh setiap rupiah yang diinvestasikan dalam HC terhadap value added organisasi. Dengan demikian VAHU dirumuskan sebagai:

VAHU $=\frac{V A}{\mathrm{HC}}$

Dimana:

$\mathrm{VA}=$ Value Added

$\mathrm{HC}=$ Human Capital mencakup beban personalia.

STVA $=$ Structural Capital Value Added. Rasio ini mengukur jumlah SC yang dibutuhkan untuk menghasilkan 1 Rupiah dari VA dan merupakan indikasi bagaimana keberhasilan SC dalam penciptaan nilai. Dengan demikian STVA dirumuskan sebagai:

$$
\text { STVA }=\frac{S C}{V A}
$$

$$
\begin{aligned}
& \text { Dimana: } \\
& \begin{aligned}
\mathrm{SC}= & \text { Structural Capital, dalam hal ini } \\
& \text { VA }-\mathrm{HC} \\
\mathrm{VA}= & \text { Value Added }
\end{aligned}
\end{aligned}
$$

Nilai VAIC dapat digolongkan menjadi empat kelompok, yakni bad performers, common performers, good performers, dan top performers. Jika nilai VAIC dibawah 2,5, maka perusahaan tergolong ke dalam kondisi bad performers yang berarti bahwa penggunaan IC di perusahaan sangat rendah karena value added yang dihasilkan perusahaan nilainya di bawah 2,5. Nilai VAIC antara 2,5 - 4 termasuk kelompok common performers, yang berarti bahwa setiap komponen IC dapat menghasilkan value added antara 2,5 dan 4. Nilai VAIC antara 4,1- 5 termasuk kelompok good performers, yang berarti perusahaan telah mampu mengelola sebagian besar IC yang dimiliki untuk menghasilkan nilai tambah bagi perusahaan dengan nilai rata-rata 4 . Sedangkan nilai VAIC diatas 5, maka termasuk ke dalam kelompok top perfomers yang berarti perusahaan mampu mengelola IC dengan sangat baik sehingga dapat menghasilkan value added bagi perusahaan di atas 5 (Kamath, 2008).

\section{Variabel Dependen}

Indikator stabilitas bank dalam penelitian ini menggunakan Z-index (STAB) merupakan sebuah proksi dari probabilitas kegagalan bank dengan mengkombinasikan ukuran profitabilitas, leverage, dan volatilitas tingkat keuntungan bank menjadi sebuah ukuran stabilitas bank (Berger et al., 2009; Wibowo, 2016) yang diformulasikan sebagai berikut:

$$
\mathrm{Zi}=\frac{\mathrm{ROA}_{\mathrm{i}}+\mathrm{E} / \mathrm{TA} \mathrm{A}_{\mathrm{i}}}{\mathrm{QROA}_{\mathrm{i}}}
$$

Nilai Zi yang semakin besar, menunjukkan tingkat stabilitas bank yang baik. Dengan kata lain, nilai $\mathrm{Zi}$ yang besar mengindikasikan kecil kemungkinan bank mengalami kebangkrutan.

Penelitian ini difokuskan pada bank umum di Indonesia sebanyak 120 bank umum yang terdiri dari Bank Persero, Bank Umum Swasta Nasional (BUSN) Devisa, BUSN non devisa, Bank Pembangunan Daerah (BPD), Bank Campuran, dan Bank Asing dengan pengamatan tahun 2013 - 2017 yang dinilai sebagai momentum perkembangan fintech di Indonesia (Teja, 2017). Industri perbankan merupakan aktivitas yang memiliki karakteristik penggunaan IC yang paling intensif diantara bidang usaha lainnya (Firer \& Williams, 2009). Selain itu, pegawai di sektor perbankan memiliki latar belakang pendidikan yang lebih homogen dibandingkan dengan bidang bisnis lainnya (Kubo \& Saka, 2002).

Variabel independen dan dependen dalam penelitian ini dianalisis dengan menggunakan regresi data panel. Persamaan regresi data panel dalam penelitian ini adalah:

$\mathrm{STAB}_{\mathrm{i}, \mathrm{t}}=\beta_{0}+\beta_{1} \mathrm{Ln}_{-} \mathrm{ATMi}_{\mathrm{t}}+\beta_{2} \mathrm{VAIC}_{\mathrm{i}, \mathrm{t}}+\varepsilon_{1}$

$\mathrm{STAB}_{\mathrm{i}, \mathrm{t}}=\beta_{0}+\beta_{3} \mathrm{Ln}-\mathrm{ATMi}_{\mathrm{t}, \mathrm{t}}+\beta_{4} \mathrm{VACA}_{\mathrm{i}, \mathrm{t}}+\beta_{5} \mathrm{VAHU}_{\mathrm{i}, \mathrm{t}}$

$$
+\beta_{6} \mathrm{STVA}_{\mathrm{i}, \mathrm{t}}+\varepsilon_{2} \ldots \ldots \ldots \ldots \ldots \ldots \ldots \ldots
$$

Dimana:

STABi, $\mathrm{t}=$ Stabilitas bank $\mathrm{i}$ pada tahun $\mathrm{t}$

Ln-ATMi,t=Logaritma natural ATM bank i pada tahun $\mathrm{t}$

VAICi, $\mathrm{t}=$ Modal intelektual bank $\mathrm{i}$ pada tahun $\mathrm{t}$

VACAi, $\mathrm{t}=$ Nilai tambah capital employee bank $\mathrm{i}$ pada tahun $\mathrm{t}$

VAHUi,t $=$ Nilai tambah human capital bank $\mathrm{i}$ pada tahun $\mathrm{t}$

STVAi, $\mathrm{t}=$ Nilai tambah struktural capital bank $\mathrm{i}$ pada tahun $\mathrm{t}$

\section{HASIL DAN PEMBAHASAN}

Selama kurun waktu 2013-2017 menunjukkan kondisi yang baik untuk tingkat stabilitas bank umum yang ada di Indonesia. Namun demikian, terdapat pula beberapa bank yang menunjukkan tingkat stabilitas yang kurang baik. Hal tersebut menggambarkan bahwa masih terdapat beberapa bank umum yang berpotensi mengalami kebangkrutan.

Terkait dengan penggunaan IC, selama kurun waktu lima tahun terakhir menunjukkan bahwa rata- 
rata bank di Indonesia masih sangat rendah dalam pemanfaatan IC yang dimiliki, dengan nilai di bawah 2,5 sehingga masih termasuk ke dalam kelompok bad performers. Hal ini menggambarkan bahwa selama rentang waktu tersebut rata-rata value added yang dihasilkan dari pemanfaatan IC masih di bawah 2,5. Disamping itu, nilai VACA sebagai salah satu komponen dari VAIC, menunjukkan rata-rata nilai yang masih rendah, yaitu sebesar 0.362137 . Hal ini menunjukkan bahwa value added yang berasal dari physical capital masih rendah. Sementara nilai VAHU menunjukkan kontribusi yang cukup tinggi dari setiap rupiah yang diinvestasikan dalam human capital. Hal ini ditunjukkan dengan nilai rata-rata VAHU sebesar 49.28476. Dan komponen terakhir dari VAIC, yakni STVA menunjukkan nilai rata-rata yang masih rendah yakni sebesar 0.977968. Hal ini berarti bahwa structural capital yang dimiliki perusahaan belum berhasil menciptakan nilai bagi perusahaan.

\section{Tabel 1}

Ringkasan Statistik

\begin{tabular}{|l|c|c|c|c|c|c|}
\hline $\begin{array}{c}\text { Ringkasan } \\
\text { Statistik }\end{array}$ & STAB & LN_ATM & VAIC & VACA & VAHU & STVA \\
\hline Mean & 10.35918 & 5.066015 & 0.362137 & 0.362137 & 49.28476 & 0.977968 \\
\hline Maximum & 345.6125 & 11.59992 & 2.323746 & 2.323746 & 205.7221 & 1.080029 \\
\hline Minimum & -22.64684 & 1.386294 & -2.944977 & -2.944977 & -111.9073 & 0.467037 \\
\hline Std.Deviasi & 22.63637 & 1.927978 & 0.316527 & 0.316527 & 28.54828 & 0.034370 \\
\hline
\end{tabular}

Sumber: Hasil olahan berdasarkan e-views, 2019

Hasil pengujian hipotesis menunjukkan variabel layanan keuangan bank yang diproksi dengan jumlah mesin atm yang dimiliki oleh bank berpengaruh signifikan terhadap stabilitas bank dengan arah hubungan positif. Hal ini menunjukkan bahwa semakin banyak ketersediaan teknologi layanan bank akan semakin tinggi stabilitas bank. Teknologi layanan bank merupakan alat yang dapat meningkatkan pendapatan bank.

Begitu pula dengan modal intelektual, hasil penelitian menunjukkan modal intelektual yang diproksi dengan VAIC berpengaruh signifikan terhadap stabilitas bank. Walaupun nilai VAIC perbankan umum di Indonesia menunjukkan kategori bad performs, namun temuan ini memberikan keyakinan bahwa modal intelektual memberikan kontribusi positif terhadap stabilitas bank. Hasil penelitian ini sejalan dengan temuan penelitian (Clarke et al., 2011; Heryana \& Saputra, 2013; Joshi, Cahill, \& Sidhu, 2010; Kamath, 2008; D. G. Mavridis, 2005)
Temuan penelitian ini memperkuat teori RBV bahwa sumber daya yang dimiliki oleh perusahaan dapat menjadikannya mampu bersaing dalam meraih keunggulan. Hal ini ditunjukkan pula dari nilai Rsquare yang menunjukan bahwa variabel independen cukup berpengaruh terhadap variabel dependen sebesar 30,22\% sebagaimana yang tampak pada tabel 2 berikut ini:

Tabel 2

Luaran Regresi Data Panel Model 1

\begin{tabular}{crrr}
\hline \hline Variable & Coefficient & t-Statistic & Prob. \\
\hline \hline C & -2.391834 & -4.238934 & 0.0000 \\
LAITM? & 1.606073 & 11.24359 & $0.0000^{* * *}$ \\
VAIC? & 5.357864 & 5.423524 & $0.0000 * * *$ \\
\hline \hline R-squared & 0.302158 & & \\
Adjusted R-squared & 0.298686 & \\
Prob(F-statistic) & 0.000000 & \\
\hline \hline & *** Signifikan pada a 1\%, & 5\%, dan 10\% \\
Sumber: Hasil olahan berdasarkan e-views, 2019 & \\
Sementara itu, hasil analisis regresi yang
\end{tabular}

dilakukan pada model 2 yang mana menunjukkan bahwa masing-masing komponen VAIC berpengaruh signifikan terhadap stabilitas bank dengan nilai Rsquare sebesar $51,99 \%$. VACA yang merupakan modal fisik berpengaruh negatif terhadap stabilitas bank. Hal ini menunjukkan bahwa modal secara fisik dapat menimbulkan beban yang besar jika bank tidak mampu untuk mengelolanya secara baik. Dengan adanya beban yang besar sebagai akibat dari ketidakmampuan pengelolaan bank dalam mengelola sumber daya fisiknya, maka akan berpengaruh terhadap kondisi stabilitas bank.

VAHU yang merupakan indikator dari jumlah value added yang dapat dihasilkan atas dana yang dikeluarkan untuk pegawai. Tabel 3 menunjukkan VAHU berpengaruh positif terhadap stabilitas bank. Hal ini menunjukkan bahwa dana pengembangan, pendidikan, serta pelatihan bagi para karyawan menjadi faktor penting bagi bank dalam rangka menjadikan pegawainya memiliki pengetahuan yang memadai dalam menunjang pekerjaannya. Dengan demikian, tentunya akan sangat menguntungkan bagi bank untuk meningkatkan kondisi stabilitasnya.

STVA sebagai komponen ketiga dari VAIC, menggambarkan value added yang diperoleh dari pegawai yang memiliki kemampuan membangun jejaring yang baik dalam melaksanakan aktivitas pekerjaannya. Dari hasil analisis ditemukan bahwa STVA berpengaruh siginifikan terhadap stabilitas bank dengan arah yang positif. Hal ini menunjukkan bahwa 
pihak karyawan mampu membangun jejaring antar pegawai maupun jejaring dengan konsumen serta para pemangku kepentingan. Sumedrea (2013) menjelaskan bahwa untuk membangun jejaring yang memadai memerlukan pra syarat yakni pegawai tersebut harus memiliki pengetahuan yang memadai. Dengan kata lain dalam konteks modal intelektual, STVA memerlukan VAHU. Dengan demikian maka dapat disimpulkan, bahwa model 1 dan 2 tidak memiliki perubahan yang berarti ketika model VAIC dihitung secara keseluruhan maupun secara parsial per komponennya. Hal ini sejalan dengan temuan para peneliti di bidang intellectual capital yang melakukan pemodelan 2 tahap, diantaranya (Clarke et al., 2011; Firer \& Williams, 2009; Goh \& Lim, 2004; D. Mavridis, 2004; Ulum, Ghozali, \& Chariri, 2008)

\section{Tabel 3}

Luaran Regresi Model 2

\begin{tabular}{crrr}
\hline \hline Variable & Coefficient & t-Statistic & Prob. \\
\hline \hline C & -4.345027 & -6.684191 & 0.0000 \\
LN_ATM? & 0.185407 & 2.629040 & $0.0089 * * *$ \\
VACA? & -0.804512 & -8.065060 & $0.0000 * * *$ \\
VAHU? & 0.083324 & 11.05533 & $0.0000 * * *$ \\
STVA? & 3.566609 & 6.802444 & $0.0000 * * *$ \\
\hline \hline R-squared & 0.519932 & \\
Adjusted R-squared & 0.515131 & \\
Prob(F-statistic) & 0.000000 & & \\
\hline \hline & *** Signifikan pada a 1\%, 5\%, dan 10\% \\
Sumber: Hasil olahan berdasarkan e-views, 2019
\end{tabular}

\section{KESIMPULAN}

Hasil penelitian menunjukkan teknologi layanan keuangan dan modal intelektual beserta komponennya secara konsisten berpengaruh terhadap stabilitas bank umum di Indonesia. Temuan penelitian ini memperkuat teori RBV dimana sumber daya berwujud dan sumber daya tidak berwujud merupakan modal utama yang harus dimiliki oleh perusahaan dalam rangka mencapai keunggulan bersaing di era perkembangan industri 4.0.

Berdasarkan pencapaian stabilitas dalam periode 2013 - 2017 perbankan di Indonesia perlu melakukan mitigasi risiko melalui inovasi pelayanan keuangan berbasis teknologi dan penguatan manajemen sumber daya manusia yang berbasis pada kompetensi yang diperlukan pada era industri 4.0. Apalagi temuan penelitian menunjukkan nilai VAIC dari perbankan umum di Indonesia berada dalam kategori bad performs.

\section{REKOMENDASI}

Penelitian ini terbatas pada perbankan umum di Indonesia, sementara di Indonesia terdapat lembaga perbankan mikro dengan populasi paling banyak dibandingkan dengan bank umum dan merupakan lembaga keuangan yang sama-sama perlu dijaga stabilitasnya dalam memberikan kontribusi terhadap pembangunan bidang usaha kecil dan menengah di Indonesia. Oleh karenanya, penelitian berikutnya dapat difokuskan pada bank berskala mikro.

7. DAFTAR PUSTAKA

Acedo, F. J., Barroso, C., \& Galan, J. L. (2006). The Resource-Based Theory: Dissemination and Main Trends. Strategic Management Journal, 27(7), 621-636. https://doi.org/10.1002/smj.532

Alubisia, L. B. (2018). Effect of Technology Based Financial Innovations on Non-Interest Income of Commercial Banks in Kenya. European Scientific Journal, 14(7), 337-349. https://doi.org/10.19044/esj.2018.v14n7p337

Beck, T. (2008). Bank Competition and Financial Stability: Friends or Foes? (Policy Reserach Working Paper No. WPS4656). Washington DC, United States of America.

Berger, A. N., Klapper, L. F., \& Ariss, R. T. (2009). Bank Competition and Financial Stability. Journal of Financial Service Research, 35, 99-118.

Campos, E. B., \& de Pablos, P. O. (2004). Innovation and Learning in The Knowledge-Based Economy: Challenges for The Firm. International Journal of Technology Management, 27(6/7), 531-532.

Chen, M.-C., Cheng, S.-J., \& Hwang, Y. (2005). An Empirical Investigation of The Relationship between Intellectual Capital and Firms' Market Value and Financial Performance. Journal of Intellectual Capital, 6(2), 159176. https://doi.org/10.1108/14691930510592771

Clarke, M., Seng, D., \& Whiting, R. H. (2011). Intellectual capital and firm performance in Australia. Journal of Intellectual Capital, 12(4), 505-530. https://doi.org/10.1108/14691931111181706

Eisdorfer, A., \& Hsu, P. H. (2011). Innovate to survive: The effect of technology competition on corporate bankruptcy. Financial Management, 40(4), 1087-1117.

Fernandez, R. O., \& Garcia, J. G. G. (2015). The Relationship Between Bank Competition and Financial Stability: A Case Study of The Mexican Banking Industry. Ensayos Revista de Economia, 52(1), 103-120.

Firer, S., \& Williams, S. M. (2009). Intellectual Capital and Traditional Measures of Corporate Performance. Journal of Intellectual Capital, 4(3), 348-360. 
Goh, P. C., \& Lim, K. P. (2004). Disclosing Intellectual Capital in Company Annual Reports Evidence from Malaysia. Journal of Intellectual Capital, 5(3), 500-510. https://doi.org/10.1108/14691930410550426

Hanum, M., Kamal, M., Mat, R. C., Rahim, N. A., \& Husin, N. (2011). Intellectual Capital and Firm Performance of Commercial Bank in Malaysia. Asian Economic and Financial Review, 2(4), 577-590.

Hauswald, R., \& Marquez, R. (2003). Information Technology and Financial Services Competition. Review of Financial Studies, 16(3), 921-948.

Helfat, C. E., \& Peteraf, M. a. (2003). The Dynamic Resource-Based View: Capability Lifecycles. Strategic Management Journal, 24(10), 9971010. https://doi.org/10.1002/smj.332

Heryana, T., \& Saputra, R. I. (2013). Implikasi Modal Intelektual terhadap Kinerja Keuangan (Studi Empiris pada Perbankan di Bursa Efek Indonesia). In Forum Keuangan dan Bisnis II (pp. 1-11). Bandung: Laboratorium Akuntansi Program Studi Akuntansi.

Joshi, M., Cahill, D., \& Sidhu, J. (2010). Intellectual Capital Performance in The Banking Sector An Assessment of Australian Owned Banks. Journal of Human Resource Costing \& Accounting, 14(2), 151-170. https://doi.org/10.1108/14013381011062649

Joshi, M., Cahill, D., Sidhu, J., \& Kansal, M. (2013). Intellectual Capital and Financial Performance: An Evaluation of The Australian Financial Sector. Journal of Intellectual Capital, 14(2), 264-285. https://doi.org/10.1108/14691931311323887

Kamath, G. B. (2007). The Intellectual Capital Performance of Indian Banking Sector. Journal of Intellectual Capital, 8(1), 96-123.

Kamath, G. B. (2008). Intellectual Capital and Corporate Performance in Indian Pharmaceutical Industry. Journal of Intellectual Capital, 9(4), 684-704. https://doi.org/10.1108/14691930810913221

Koetter, M., \& Noth, F. (2013). IT Use, Productivity, and Market Power in Banking. Journal of Financial Stability, 9(4), 695-704.

Kor, Y. Y., \& Mahoney, J. T. (2004). Edith Penrose's (1959) Contributions to the Resource-Based View of Strategic Management. Journal of Management Studies, 41(1), 183-191.

Kubo, I., \& Saka, A. (2002). An Inquiry into The Motivations of Knowledge Workers in The Japanese Financial Industry. Journal of Knowledge Management, 6(3), 262-271.
Leibenstein, H. (1966). Allocative Efficiency vs XEfficiency. The American Economic Review, 56(3), 392-415.

Maheran, N., \& Muhammad, N. (2009). Intellectual Capital Efficiency and Firm's Performance : Study on Malaysian Financial Sectors. International Journal of Economics and Finance, 1(2), 206-213.

Mavridis, D. (2004). The Intellectual Capital Performance of the Japanese Banking Sector. Journal of Intellectual Capital, 5(3), 92-115.

Mavridis, D. G. (2005). Intellectual Capital Performance Drivers in the Greek Banking Sector. Management Research News, 28(5), 63-62.

Newbert, S. L. (2007). Empirical Research on The Resource-Based View of The Firm: An Assessment and Suggestions for Future Research. Strategic Management Journal, 28, 121-146. https://doi.org/10.1002/smj

Nicolo, G. De, \& Lucchetta, M. (2013). Bank Competition and Financial Stability: A General Equilibrium Exposition. Oslo, Canada.

OJK. (2017). Statistik Perbankan Indonesia. Jakarta, Indonesia.

Pulic, A. (1998). Measuring the Performance of Intellectual Potential in Knowledge Economy. In The 2nd McMaster World Congress on Measuring and Managing Intellectual Capital by the Austrian Team for Intellectual Potential (pp. 1-20).

Ray, G., Barney, J. B., \& Muhanna, W. A. (2004). Capabilities, Business Processes, and Competitive Advantage: Choosing The Dependent Variable in Empirical Test of The Resource-Based View. Strategic Management Journal, 25, 23-37.

Rugman, A. M., \& Verbeke, A. (2002). Edith Penrose's Contribution to The ResourceBased View of Strategic Management. Strategic Management Journal, 23(8), 769780. https://doi.org/10.1002/smj.240

Sathye, S., \& Sathye, M. (2017). Do ATMs Increase Technical Efficiency of Banks in a Developing Country? Evidence from Indian Banks. Australian Accounting Review, 27(80), 101-111. https://doi.org/10.1111/auar.12110

Sumedrea, S. (2013). Intellectual Capital and Firm Performance: A Dynamic Relationship in Crisis Time. Procedia Economics and Finance, 6(13), 137-144. https://doi.org/10.1016/S22125671(13)00125-1

Surat Keputusan Direksi Bank Indonesia (1999). Bank Indonesia. 
Teja, A. (2017). Indonesian Fintech Business: New Innovations or Foster and Collaborate in Business Ecosystems? The Asian Journal of Technology Management, 10(1), 10-18.

Ulum, I., Ghozali, I., \& Chariri, A. (2008). Intellectual Capital dan Kinerja Keuangan Perusahaan: Suatu Analisis dengan Pendekatan Partial Least Squares. In Simposium Nasional Akuntansi XI (Vol. 19, pp. 1-31).

Wibowo, B. (2016). Stabilitas Bank, Tingkat Persaingan Antar Bank dan Diversifikasi Sumber Pendapatan : Analisis Per Kelompok Bank di Indonesia. Jurnal Manajemen Teknologi, 15(2), 172-195. 